\title{
VCAM1 wt Allele
}

National Cancer Institute

\section{Source}

National Cancer Institute. VCAM1 wt Allele. NCI Thesaurus. Code C51231.

Human VCAM1 wild-type allele is located within 1p32-p31 and is approximately $19 \mathrm{~kb}$ in length. This allele, which encodes vascular cell adhesion protein 1, is involved in the regulation of cellular adhesion. 